with the new Charter its remit was broadened to include involvement in agriculture, forestry, tourism, transport and the development of infrastructure, with preference for projects which promote regional co-operation.

Official language: English.

Headquarters: 4 Nile Ave., PO Box 7128, Kampala, Uganda.

Website: http://www.eadb.org

Chair of the Governing Council: Syda Bbumba (Uganda).

\section{Economic Community of Central African States (CEEAC)}

The Economic Community of Central African States (Communauté Economique des Etats de l'Afrique Centrale) was established in 1983 to promote regional economic co-operation and to establish a Central African Common Market. There are plans for both a common market and a single currency.

Members. Angola, Burundi, Cameroon, Central African Republic, Chad, Democratic Republic of the Congo, Republic of the Congo, Equatorial Guinea, Gabon, São Tomé e Príncipe.

Headquarters: BP 2112, Libreville, Gabon.

Website (French only): http://www.ceeac-eccas.org

President: Lieut.-Gen. Idriss Déby (Chad).

Secretary General: Nassour Guelengdoukssia Ouaidou (Chad).

\section{Economic Community of West African States (ECOWAS)}

Founded in 1975 as a regional common market, ECOWAS later also became a political forum involved in the promotion of a democratic environment and the pursuit of fundamental human rights. In July 1993 it revised its treaty to assume responsibility for the regulation of regional armed conflicts, acknowledging the inextricable link between development and peace and security. Thus it now has a new role in conflict management and prevention through its Mediation and Security Council, which monitors the moratorium on the export, import and manufacture of light weapons and ammunition. However, it still retains a military arm, the Economic Community of West African States Monitoring Group (generally known as ECOMOG). It is also involved in the war against drug abuse and illicit drug trafficking. There are plans to introduce a single currency, the eco, by 2020 .

Members. Benin, Burkina Faso, Cape Verde, Côte d'Ivoire, Gambia, Ghana, Guinea, Guinea-Bissau, Liberia, Mali, Niger, Nigeria, Senegal, Sierra Leone, Togo.

Organization. The institutions of ECOWAS are: the Commission, the Community Parliament, the Community Court of Justice and the ECOWAS Bank for Investment and Development.

Official languages: English, French, Portuguese.

Headquarters: 101 Yakubu Gowon Crescent, Asokoro, Abuja,

Nigeria.

Website: http://www.ecowas.int

Email: info@ecowas.int

ECOWAS Commission President: Kadré Désiré Ouedraogo

(Burkina Faso).

\section{Further Reading}

Jaye, Thomas, Garuba, Dauda and Amadi, Stella, (eds.) ECOWAS and the Dynamics of Conflict and Peace-building. 2011

\section{Intergovernmental Authority on Development}

The Intergovernmental Authority on Development was created on 21 March 1996 and has its origins in the Intergovernmental Authority on Drought and Development, which had been established in 1986. It has three priority areas of co-operation: conflict prevention, management and humanitarian affairs; infrastructure development; food security and environment protection

Members. Djibouti, Ethiopia, Kenya, Somalia, South Sudan, Sudan, Uganda. Eritrea was formerly a member but withdrew in April 2007.

Headquarters: Ave. Georges Clemenceau, PO Box 2653,

Djibouti, Republic of Djibouti.

Website: http://igad.int

Executive Secretary: Mahboub Maalim (Kenya).

\section{Lake Chad Basin Commission}

Established by a Convention and Statute signed on 22 May 1964 by Cameroon, Chad, Niger and Nigeria, and later by the Central African Republic (Sudan has also been admitted as an observer), to regulate and control utilization of the water and other natural resources in the Basin; to initiate, promote and co-ordinate natural resources development projects and research within the Basin area; and to examine complaints and promote settlement of disputes, with a view to promoting regional co-operation.

In Dec. 1977, at Enugu in Nigeria, the 3rd summit of heads of state of the commission signed the protocol for the Harmonization of the Regulations Relating to Fauna and Flora in member countries, and adopted plans for the multi-donor approach towards major integrated development for the conventional basin. An international campaign to save Lake Chad following a report on the environmental degradation of the conventional basin was launched by heads of state at the 8 th summit of the Commission in Abuja in March 1994. The 10th summit, held in N'Djaména in 2000, saw agreement on a US\$1m. inter-basin water transfer project.

The Commission's budget for 2011 was $3 \cdot 3 \mathrm{bn}$. francs CFA. It also receives assistance from various international and donor agencies including the FAO, and UN Development and Environment Programmes.

Official languages: English, French.

Headquarters: BP 727, CBLT Siège, Rond Point de l'Etoile,

N’Djaména, Chad.

Executive Secretary: Sanusi Imran Abdullahi (Nigeria).

\section{Niger Basin Authority}

As a result of a special meeting of the Niger River Commission (established in 1964), to discuss the revitalizing and restructuring 